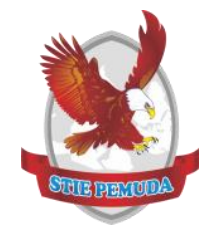

International Journal of Global Accounting, Management, Education, and Entrepreneurship (IJGAME 2)

URL : https://jurnal.stiepemuda.ac.id/index.php/ijgame2

P- ISSN : 2723-2948

E-ISSN : :2723-2204

\title{
ANALYSIS OF INFLUENCE OF CAPITAL STRUCTURE, COMPANY SIZE, COMPANY GROWTH AND PROFITABILITY ON CORPORATE VALUE
}

\author{
Naning Tri Rahayu , ${ }^{1}$ Abu Darim ${ }^{2}$ \\ Stie Widya Darma Surabaya, ${ }^{1}$ Institut KH. Abdul Chalim ${ }^{2}$ \\ Naningtrirahayu1@gmail.com, ${ }^{1}$ abudarim.darim@gmail.com ${ }^{2}$
}

\begin{abstract}
This study has a purpose to explain the significance of the effect of capital structure, firm size, company growth, and profitability affect partially or simultaneously on the value of manufacturing companies listed on the IDX. The population in this study were 144 manufacturing companies listed on the Stock Exchange, a sample of 74 companies during the study period namely 20102016 using purposive sampling method with predetermined criteria. The data source used in this study is secondary data. Multiple linear regression is the analytical technique used in this study. After testing, the results of the capital structure, company growth, and profitability are obtained simultaneously and have a significant effect on the value of the company. Partially the capital structure has a negative and significant effect on firm size, company growth and profitability have a positive and significant effect on the value of the company.
\end{abstract}

Keywords: value of the company, capital structure, firm size, company growth, and profitability.

\section{INTRODUCTION}

The capital market or stock exchange (Stock Exchange) is a market that deals with the buying and selling of securities of companies that are already listed on the stock exchange. A Securities Exchange is a party that organizes and provides a system or means to bring together offers and requests for other parties' securities with the aim of trading securities between themselves. The Indonesia Stock Exchange has an important role as a means for the public to invest, which is an alternative investment Company value is the market value of a company's equity plus the value of debt. Thus, the addition of the company's equity to the company's debt can reflect the value of the company. Company value can describe the state of the company. With the good value of the company will be considered good by investors, and vice versa increased corporate value is characterized by a high rate of return on investment from shareholders.

According to Hartono $(2000 ; 79)$ There are three types of valuations related to shares, namely book value, market value and intrinsic value. Book value is the value of shares according to the books of the issuer. Market value is the book value of shares in the stock market and intrinsic value is the true value of shares. Investors need to know and understand the three values as important information in making stock investment decisions because it can help investors to know which stocks are growing and cheap. One approach in determining the intrinsic value of a stock is the price book value (PBV). PBV or price per book value ratio is the relationship between the stock market price 
and book value per share. Capital structure is a balance or comparison between long-term debt with own capital (Riyanto, 2001: 62). Capital structure can be defined as permanent financing consisting of long-term debt, preferred stock and shareholder capital (Weston and Copeland, 2008). Mogdiliani and Miller, (1963: 53) state the value of a company is determined by the capital structure. The problem of capital structure is a problem that is very important for every company, because the good or bad capital structure will have a direct effect on the company's financial position. A company that has a bad capital structure, which has a very large debt will put a heavy burden on the company concerned (Riyanto, 2011: 85).

Company size variable (size) is an indicator that shows the company's financial strength. The size of the company is considered able to influence the value of the company, because the larger the size or scale of the company, the easier it will be for companies to obtain funding sources both internal and external. This research is in accordance with Soliha and Taswan (2002), Hermuningsih (2013) shows that company size has a positive effect on firm value. This research is different from Hargiansyah (2015) which states that company size has no effect on firm value. Company size variable (size) is an indicator that shows the company's financial strength. The size of the company is considered able to influence the value of the company, because the larger the size or scale of the company, the easier it will be for companies to obtain funding sources both internal and external. This research is in accordance with Soliha and Taswan (2002), Hermuningsih (2013) shows that company size has a positive effect on firm value. This research is different from Hargiansyah (2015) which states that company size has no effect on firm value.

Companies to be able to carry out operational activities must be in a favorable condition or profitable. Company value can also be influenced by the size of the profitability generated by the company. Kasmir (2013: 196) defines profitability is the extent to which companies generate profits from sales and investment companies. If the company's profitability is good, the stakeholders consisting of creditors, suppliers, and investors will see the extent to which the company can generate profits from sales and investment of the company.

\section{THEORETICAL REVIEW AND HYPOTHESES}

\section{The value of the company}

Company value is defined as market value because the value of the company can provide maximum shareholder prosperity if the share price increases. According to Husnan and Pudjiastuti (2006: 258) the value of the company is the price that prospective buyers are willing to pay if the company is sold. Various policies that have been taken by management in an effort to increase the value of the company through increasing the prosperity of owners and shareholders as reflected in the share price. (Bringham and Houston, 2010: 19).

According to Robert, Ang (1997) Price to Book Value (PBV) is a market ratio that is used to measure the performance of the stock market price against the book value. Theoretically, stock prices must describe the stock book itself. Price- to-book value ratios are generally used to value stocks from the manufacturing sector because the assets of manufacturing companies have relatively similar market 
values and book values (Tandellin, 2001: 323). This ratio reflects the company's performance as seen from the company's stock price. Ideally, the stock price compared to the book value would be close to one. The greater this ratio, reflects the better the company's performance.

\section{Capital Structure}

Capital structure according to Riyanto (2011: 22) is a permanent expenditure that reflects the consideration of long-term debt with own capital, capital is a reflection of the balance between long-term debt and own capital. The need for capital is very important in building and ensuring the survival of the company so that financial managers must accurately and accurately determine the capital structure.

An optimal capital structure is a capital structure that optimizes the balance between risk and return thereby maximizing stock prices. The target capital structure (optimal capital structure) of a company is defined as a structure that will maximize the company's stock price (Brigham and Houston, 2010: 155). The importance of capital structure for each company because it has a very large influence on corporate finance and corporate value.

Several concepts of capital structure theory (leverage) put forward by experts include traditional approaches, trade off theory, and pecking order theory.

1) Traditional Approach

The traditional approach argues for an optimal capital structure. In other words capital structure has an influence on firm value. The capital structure can be changed so that optimal company value can be obtained, depending on how much the debt is used. If the use of debt is too high then the value of the company will decrease because debt becomes higher, the cost of capital increases so that the risk of using debt is higher and makes the cost of capital stock also increase.

2) Trade-Off Theory

This theory discusses the relationship between capital structure and firm value. The trade-off model assumes that the company's capital structure is the result of trade-offs from tax profits using debt with costs that will arise as a result of using that debt. The essence of trade-off theory in capital structure is to balance the benefits and sacrifices that arise as a result of using debt. As far as greater benefits, additional debt is still permitted. If the sacrifice due to the use of debt is already greater, then the additional debt is not allowed.

3) Pecking Order Theory

This theory was put forward by Myers and Majluf (1984) in Sugiarto (2009). This theory briefly states that the company likes internal financing (funding from the company's operating results in the form of retained earnings). The sequences of the use of funding sources with reference to the pecking order theory according to (Kaaro, 2003) in (Saidi, 2004) are:

a. Companies tend to use internal financing from company retained earnings.

b. If external funding is needed, the company will issue debt (debt) 
first, then if the use of debt is still insufficient the company will issue new shares.

According to Kusumajaya (2011: 101), capital structure is a balance or comparison between the amount of long-term debt with own capital. Therefore, capital structure is measured by debt to equity ratio (DER). Debt to equity ratio (DER) is the ratio used to measure the level of debt use to the total shareholder's equity owned by the company (Robert Ang, 1997).

Total debt is total liabilities (both short-term and long-term debt) while total shareholder's equity is total own capital (total paid-in capital and retained earnings) owned by the company. This ratio shows the composition or capital structure of total loans (debt) to the total capital owned by the company. The higher the dept to equity ratio (DER) shows the composition of total debt (short-term and long-term) is greater than the total own capital, so that the greater the company's burden on external parties (creditors) (Robert Ang, 1997).

\section{Company Size (Firm Size)}

Company size is the average of total net sales for the year up to several years. In this case sales are greater than variable costs and fixed costs, then the amount of income before tax will be obtained. Conversely, if sales are smaller than variable costs and fixed costs, the company will suffer losses (Brigham and Houston 2006).

\section{Company Growth}

Company growth is an increase or decrease in total assets owned by a company. Company growth is calculated as a percentage change in assets in a particular year against the previous year. Growth is a change (decrease or increase) in total assets owned by the company. Asset growth is calculated as a percentage change in assets at a certain time against the previous year (Saidi, 2004). The company's growth opportunities will provide a good signal for investors. So that it will affect investors in investing. The company has assets that are used in the company's operational activities. Assets that are owned by the company are a form of fixed investment of the company. Asset growth illustrates the growth of company assets that will affect the profitability of companies which believe that the percentage change in total assets is a better indicator of measuring company growth (Putrakrisnanda, 2009).

In this study the indicator used is Assets Growth which means it is a depiction of an increase or decrease (growth) in assets every year. Companies that have high growth tend to invest back into the company. The higher the growth rate, the higher the need for funds for investment. For this reason, the company will use the profits obtained to finance its investments, rather than distributing dividends.

\section{Profitability}

Profitability is the ability of a company to generate profits (profit) at the level of sales, assets and certain share capital (Husnan, 2001). This profitability provides an illustration of how effectively the company operates so as to provide benefits to the company.

Company profitability is one of the bases for evaluating the condition 
of a company, for that we need an analytical tool to be able to assess it. The analysis tool in question is financial ratios. Profitability ratios measure the effectiveness of management based on returns obtained from sales and investment returns.

Profitability also has an important meaning in the effort to maintain its survival in the long run, because profitability shows whether the business entity has good prospects in the future. Profitability in this study was measured using Return on equity (ROE) which is the rate of return on the owner's equity. Owner's equity is the total net assets of the company. Return on equity or return on net is worth measuring the company's ability to obtain available profits for the company's shareholders (Agus Sartono, 2001: 119).

Return on equity (ROE) is a ratio that shows how much the company's ability to generate net income to return equity to shareholders (Hargiansyah, 2015). Return on equity (ROE) is commonly used by investors to calculate the rate of return on a company's profits from its equity. Return on equity (ROE) is chosen as a proxy of profitability because ROE is used to assess the level of profits obtained at a certain time period compared to the capital owned by the company.

\section{Framework}

Effects of Capital Structure, Company Size, Company Growth, and Profitability on Company Value

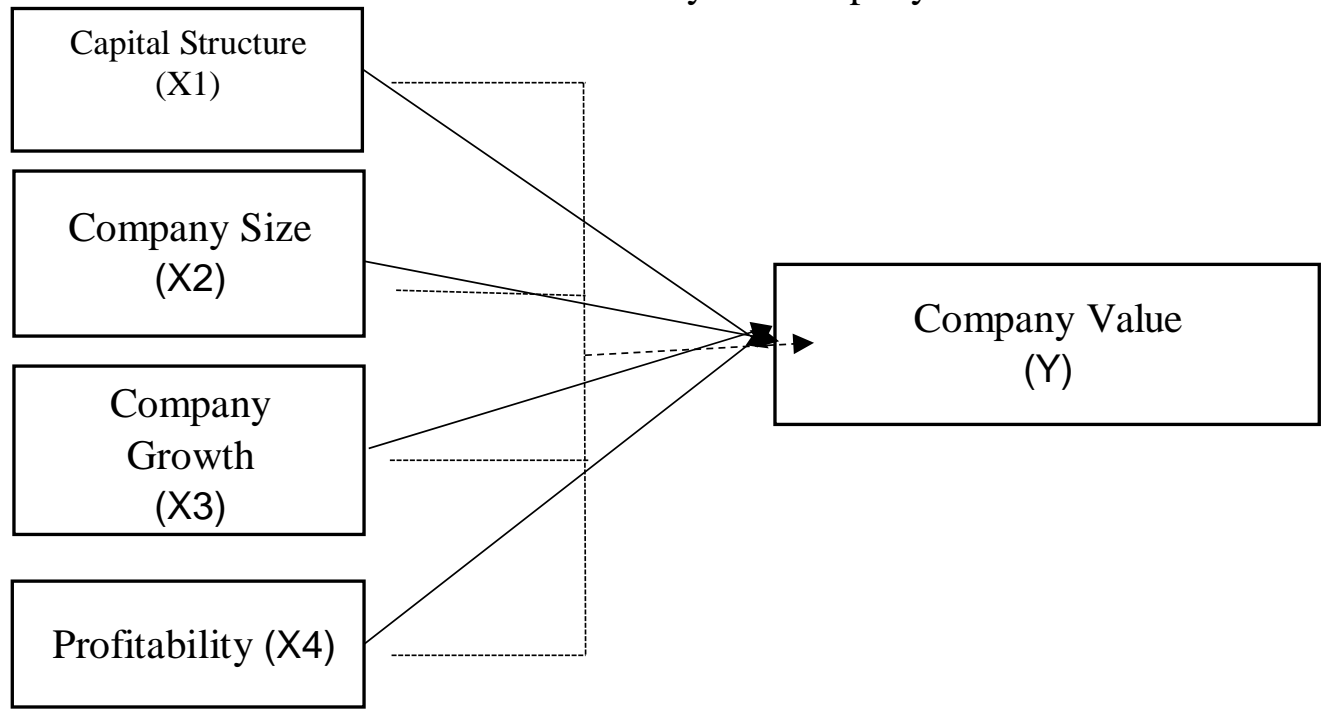

Keterangan :

----------- = Simultaneous Test $=$ Test partially

\section{RESEARCH METHODS}

\section{Population and Research Samples}

The population in this study are manufacturing companies 
listed on the Indonesia Stock Exchange during the period 2010-2016. The sampling technique used was purposive sampling. The criteria used to select the sample are as follows:

1) Manufacturing companies listed on the Indonesia Stock Exchange with ICMD (Indonesian capital market directory) classification in 2010-2016. 2) Manufacturing companies that issue complete financial statements from 2010-2016 in a row. 3) Manufacturing companies that present the rupiah in the 2010-2016 financial statements.

\section{RESULTS AND DISCUSSION}

\section{Research Sample Data}

The study was conducted from the period 2010-2016 on manufacturing companies on the Indonesia Stock Exchange. The research sample of 74 manufacturing companies on the Stock Exchange, where the method used is purposive sampling, which is a sampling method by establishing certain criteria, which can be seen sampling as follows:

Table 1

Classification of Manufacturing Companies on the IDX Period 2010 2016

\begin{tabular}{|l|c|}
\hline \multicolumn{1}{|c|}{ Criteria } & amount \\
\hline $\begin{array}{l}\text { Manufacturing companies listed on the Indonesia Stock } \\
\text { Exchange with ICMD (Indonesian capital } \\
\text { market directory) classification in 2010-2016 }\end{array}$ & 144 \\
\hline $\begin{array}{l}\text { Manufacturing companies that did not publish } \\
\text { complete financial statements from 2010-2016 in a row }\end{array}$ & 57 \\
\hline $\begin{array}{l}\text { Manufacturing companies that do not present the } \\
\text { rupiah in the 2010-2016 financial statements }\end{array}$ & 13 \\
\hline Number of Samples & $\mathbf{7 4}$ \\
\hline
\end{tabular}

Source: Indonesian Capital Market Directory, 2010-2016

\section{Descriptive statistics}

Descriptive statistics provide an overview of the variables used in this study. The following is a description of the Capital Structure (DER), company size, Company Growth, and Profitability (ROE) as an independent variable and Company Value (PBV) as the dependent value. The purpose of this analysis is to provide a general description of the mean, minimum, maximum, and standard deviation of each of these variables. The data is processed with SPSS 23.0 software to obtain the results as presented in table 2 as follows: 
Table 2

Descriptive Statistics Sample Data

\begin{tabular}{|l|r|r|r|r|r|}
\hline & N & \multicolumn{1}{|c|}{ Minimum } & Maximum & \multicolumn{1}{c|}{ Mean } & \multicolumn{1}{c|}{$\begin{array}{c}\text { Std. } \\
\text { Deviation }\end{array}$} \\
\hline The value of the company & 74 & 0,02 & 2,61 &, 4627 &, 48391 \\
Capital structure & 74 & 0,01 & 2,53 &, 3131 &, 40854 \\
Company size & 74 & 10,25 & 18,08 & 14,1723 & 1,57259 \\
Asset growth & 74 & 1,46 & 4,39 & 1,0846 &, 89047 \\
Profitability & 74 & $-0,33$ & 15,66 & 2,3197 & 2,57210 \\
Valid N & 74 & & & & \\
(listwise) & & & & & \\
\hline
\end{tabular}

Sources; SPSS output version 23; Descriptive statistics

\section{Classic assumption test}

Table 3

Multicolinierity Test Results

\begin{tabular}{|ll|r|r|}
\hline \multirow{2}{*}{\multicolumn{1}{|c|}{ Model }} & \multicolumn{2}{|c|}{ Collinearity Statistics } \\
\cline { 3 - 4 } & Tolerance & \multicolumn{2}{|c|}{ VI } \\
\hline 1 & (Constant) &, 836 & 1,197 \\
& Capital structure &, 965 & 1,036 \\
& Company size &, 807 & 1,239 \\
& Asset growth &, 966 & 1,035 \\
& Profitability & & \\
& & &
\end{tabular}

Source: SPSS output version 23; Variance inflation factor

The results of the VIF test in Table 3 show that the four independent variables did not occur multicollinearity because the VIF value $<10$ and $\mathrm{TOL}>0.1$.

Figure 1 Scaterplot

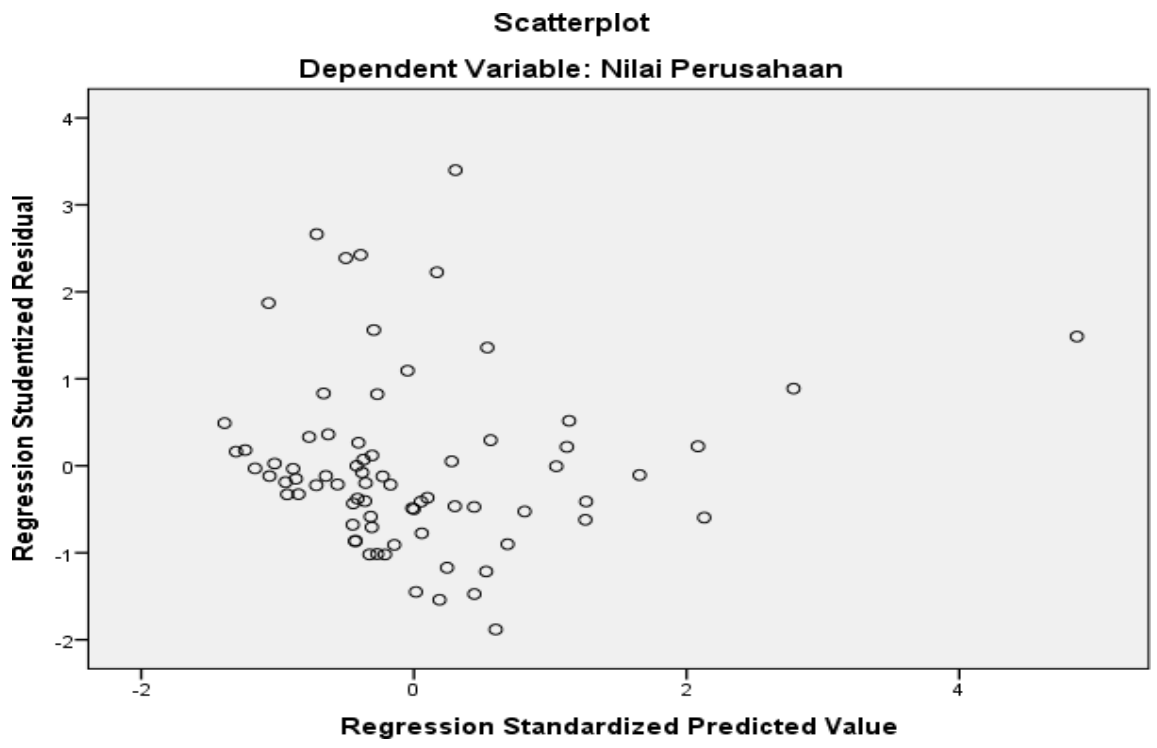

Source: SPSS output version 23; Scaterplot 
The scatterplot graph shows that the points spread randomly and scattered both above and below the zero (0) on the Y axis, do not gather in one place, and do not form certain patterns so that it can be concluded that there is no heteroscedasticity in the regression model in the sense that the variance all of these variables indicate an independent variable can be used to predict the value of the company (PBV) in manufacturing companies during the period 2010-2016.

Table 4. Autocorrelation Test Results

\begin{tabular}{|l|r|r|r|r|l|}
\hline Model & $\mathrm{R}$ & $\mathrm{R}$ Square & $\begin{array}{l}\text { Adjusted } \\
\mathrm{R} \\
\text { Square }\end{array}$ & $\begin{array}{c}\text { Std. Error of } \\
\text { the } \\
\text { Estimate }\end{array}$ & $\begin{array}{l}\text { Durbin- } \\
\text { Watson }\end{array}$ \\
\hline 1 & $\begin{array}{l}478 \\
\mathrm{a}\end{array}$ &, 228 &, 18 &, 4446 & 1,809 \\
\hline
\end{tabular}

Source: SPSS output version 23; model summary

Based on the results of the Durbin-Watson test of 1.809; whereas in the Durbin-Watson (DW) table for "k" $=4$ and $N=74$ the large Durbin-Watson table: dl (outer limit) $=1.5112$ and du (inner limit) $=1.7383 ; 4-\mathrm{du}=2.2617$ and $4-\mathrm{dl}=2.4888$. Because the DurbinWatson (DW) value is 1.809 greater than the limit (du) 1.7383 and Durbin-Watson (DW) is less than 2.4888, it can be concluded that the Durbin-Watson (DW) -test cannot reject the $\mathrm{H} 0$ states that there is no positive or negative autocorrelation or it can be concluded that there is no autocorrelation.

\section{Hypothesis testing}

Table 5 Results of Multiple Regression Analysis

\section{Coefficient}

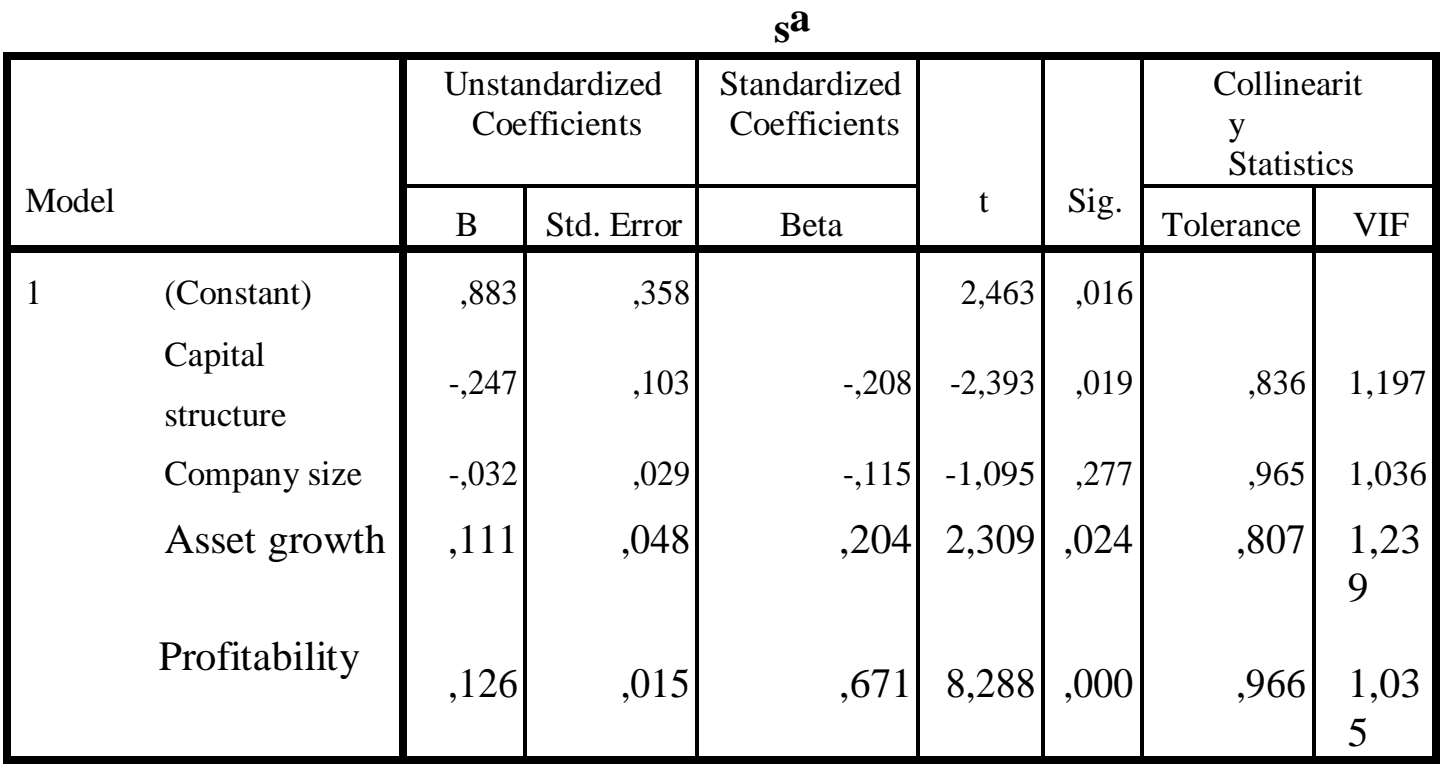

The coefficient of determination test is used to test the goodness- 
fit of the regression model. The results of the coefficient of determination test are known Adjusted R Square value of 0.538. This means that 53.8\% of the influence of the dependent variable that is firm value (PBV) of manufacturing companies can be explained by variable capital structure (DER), company size (LnSize), company growth, profitability (ROE). While the remaining value of 0.462 or equal to $46.2 \%$ is explained by other variables not included in this study.

From the results of multiple linear regression analysis with the SPSS program as shown in Table 4.5, the linear regression equation that is formed is: PBV $=883-0.247 \mathrm{DER}-$, 053Lnsize + 0.111 Asset Growth $+0.126 \mathrm{ROE}$

From the multiple linear regression equation above, it can be analyzed as follows: From the multiple linear regression equation above, it can be analyzed as follows:

1. A constant of 0.883 states that if the independent variable is considered constant, the firm's value (PBV) is 0 . This indicates that the value is positive and the contribution of the independent variable changes to the dependent variable is quite large.

2. The capital structure regression coefficient of -0.274 statistically shows that there is a negative influence of capital structure on firm value. with the calculated value for the capital structure variable (DER) is 2.339 with a significance level of 0.019 . Judging from the tcount that is greater than ttable that is 2.339> 1.99444 and a significance level smaller than 0.05 then $\mathrm{H} 1$ is proven or in other words the capital structure (DER) influences and is significant on the value of the manufacturing company (PBV) of the listed companies in IDX in 2010-2016.

3. Regression coefficient of company size of - 0.053 statistically shows that there is a negative influence of company size on firm value. The calculated value for the company size variable (LnSize) is 1.095 with a significance level of 0.277 . Judging from the t-test that is smaller than the table that is $1.095<1.99444$ and a significance level greater than 0.05 accepts $\mathrm{H} 0$ and rejects $\mathrm{H} 1$ in other words the size of the company has no effect and is not significant to the firm's value (PBV) of manufacturing companies listed on IDX in 2010-2016.

4. A constant of 0.883 states that if the independent variable is considered constant, then the value of the company (PBV) is 0 . This states that the value is positive and the contribution of the independent variable changes to the dependent variable is quite large.

5. The capital structure regression coefficient of -0.274 statistically shows that there is a negative influence of the capital structure on firm value. with the calculated value for the capital structure variable (DER) is 2.339 with a significance level of 0.019. Judging from the t-test that is greater than ttable that is 2.339> 1.99444 and a significance level smaller than 0.05 then $\mathrm{H} 1$ is proven or in other words the capital structure (DER) influences and is significant on the 
value of the manufacturing company (PBV) of the listed companies in IDX in 2010-2016.

6. Regression coefficient of company size of - 0.053 statistically shows that there is a negative influence of company size on firm value. The calculated value for the company size variable (LnSize) is 1.095 with a significance level of 0.277 . Judging from the t-test that is smaller than the table that is $1.095<1.99444$ and a significance level greater than 0.05 accepts $\mathrm{H} 0$ and rejects $\mathrm{H} 1$ in other words the size of the company has no effect and is not significant to the firm's value (PBV) of manufacturing companies listed on IDX in 2010-2016.

7. Regression coefficient of company growth of 0.111 statistically shows the positive influence of company growth on firm value. The calculated value for the variable company growth (asset growth) is 2.309 with a significance level of

0.024. Judging from the tcount that is greater than ttable that is 2.309> 1.99444 and a significance level smaller than 0.05, then rejecting $\mathrm{H} 0$ and accepting $\mathrm{H} 1$ in other words company growth (asset growth) has a positive and significant effect on the company's value (PBV) of the company manufacturers listed on the Indonesia Stock Exchange in 2010-2016.

8. The profitability regression coefficient of 0.126 statistically shows the positive effect of profitability on firm value. the calculated value for the profitability variable (ROE) is 8.288 with a significance level of .000 . Judging from the t-test that is greater than ttable that is 8.288> 1.99444 and a significance level of less than 0.05 rejects $\mathrm{H} 0$ and accepts $\mathrm{H} 1$ or in other words profitability (ROE) has a positive and significant effect on firm value (PBV) of manufacturing companies listing on the Indonesia Stock Exchange in 2010-2016.

The results of the analysis using 4 independent variables, indicate that the firm size variable has no effect on the research model, where the results of the analysis show a negative regression coefficient (-), meaning that the larger the size of the company the more down the value of the company. The theory should be that the larger the size of the company, the value of the company will also increase, because because in this analysis the model needs to be improved by removing / eliminating company size variables. The results of multiple linear regression analysis by not including the firm size variable as follows:

Table 6. Analysis results after eliminating company size variables

\begin{tabular}{|ll|r|r|r|}
\hline \multirow{2}{*}{ Model } & \multicolumn{2}{|c|}{$\begin{array}{c}\text { Unstandardized } \\
\text { Coefficients }\end{array}$} & \multirow{2}{*}{$\mathrm{t}$} & \multirow{2}{*}{ Sig. } \\
\cline { 3 - 3 } & \multicolumn{2}{|c|}{$\mathrm{B}$} & & \\
\hline $1 \quad$ (Constant) &, 130 & 1,868 &, 066 \\
& Capital structure &,- 222 & $-2,113$ &, 038 \\
& Company growth &, 094 & 2,270 &, 057 \\
& Profitability &, 129 & 8,331 &, 000 \\
\hline
\end{tabular}


SSources; SPSS output version 23; T test after eliminating firm size variables

From the first hypothesis testing the results obtained are:

1. Capital structure variable (DER) has a negative and not significant effect on firm value (PBV). Testing this hypothesis can be interpreted that the addition of debt made by the company to expand the business can reduce the value of the company. The negative relationship between DER and PBV is because manufacturing companies use more debt than their own capital. The use of high debt will cause bankruptcy costs, agency costs, interest expenses and the greater and the like. The optimal level of debt occurs when an additional tax savings equals the additional cost of bankruptcy. So the Trade Off theory explains that before reaching the maximum point, debt will be cheaper than stock sales because of the tax shield. The implication is that the higher the debt, the lower the value of the company. However, after reaching the maximum point, the use of debt by the company becomes unattractive because the company must bear agency costs, bankruptcy and interest costs that cause the company's value to go down. This research is in accordance with Chowdhury (2010), Hermuningsih (2012), Hamidy, at all ( 2015), Dewi M. And Sudiartha (2017), Bayu Eko (2017) who stated that the greater the use of debt in the capital structure, the increasing return on the equity of a company, and this study rejected the results of research by Soliha and Taswan (2002), Hidayati ( 2010), Dewa Ayu, et al (2012), Isabella (2017) that capital structure has a positive and significant effect on the value of the company, which means that the company's capital structure policy that uses more debt will increase stock prices.

2. The company's growth variable has a positive and not significant effect on firm value. Based on the results of the study means that the faster growth of the company will result in an increase in the value of the company. This can happen because the faster the company's growth, the greater the funds that must be available for corporate investment activities, both from outside and inside the company. The company's growth is expected by internal and external parties of the company, because good growth marks the development of the company. From an investor's perspective, the growth of a company is a sign that the company has favorable aspects, and investors will expect a rate of return from the investments made to show good development. These findings prove that the effect of company growth on firm value has a positive and significant effect. The test results are in accordance with previous research conducted by Wardjono (2010), Suwardika and Mustanda (2017). This research rejects the results of Febrianti's (2012) research, Roosiana (2016) that company growth has a negative and significant effect on firm value. 
3. Profitability variables have a positive and significant effect on the value of manufacturing companies listed on the Indonesia Stock Exchange in the period 2010-2016. This proves that the higher the value of ROE, the company can generate high profits for shareholders, it will make investors interested in investing their shares in companies that provide large profits to shareholders. High profit will give an indication of a good company prospect so that it can trigger investors to participate in increasing share demand. The increasing demand for shares will cause the value of the company to increase. But besides that profitability can also reduce the value of the company, this can occur because in increasing profitability, the company will increase its operational activities so that the costs incurred from this activity will also increase. This research is in accordance with the results of Pratama and Wiksuana's research (2016), Rachmawati et.al, (2015) Munawaroh (2014). This study does not support research conducted by Sari and Sidiq (2013), Moniaga (2013), Kamila and Yuniati (2017) which state that profitability has no effect on firm value.

The results of testing the second hypothesis can be explained that the variables simultaneously capital structure, company growth and profitability affect the value of the company in manufacturing companies listed on the Indonesia Stock Exchange. The value of the company has increased or decreased influenced by variable capital structure, company growth and profitability. The use of debt policy can be used to create desired company value, but debt policy also depends on the growth of the company which is also related to the size of the company. This means that large companies with good growth rates are relatively easier to access to the capital market. The better company growth and company profitability means the company's prospects in the future are considered better, meaning that the company's value will also be assessed better in the eyes of investors. If the company's ability to generate profits increases, the share price will also increase (Husnan, 2001: 317).

\section{Conclusion}

From the data analysis that has been done to determine the effect of capital structure, company growth and profitability on the value of manufacturing companies listed on the Indonesia Stock Exchange in 2010-2016, it can be concluded as follows:

\section{Simultaneously}

Capital structure, company growth, and profitability have a significant positive effect on corporate value simultaneously by $53.8 \%$ and the remaining $46.2 \%$ is influenced by other independent variables.

2. Partially

Variable capital structure has a negative and significant effect on firm value, company growth partially has a positive but not significant effect on firm value while profitability is partially positive and significant effect on firm value of manufacturing companies listed on the Indonesia Stock Exchange in 2010-2016. 


\section{REFERENCES}

Agus Sartono, 2001. Financial Management Theory and Applications. Yogyakarta: BPEF-YOGYAKARTA.

Ahmed and Nanda. 2004. "Style Investing: Incorporating PBV in Value Stocks". The Journal of Portfolio Management.

Arikunto, S. (2013). Research Procedure: A Practical Approach. Jakarta: Rineka Cipta.

Bayu Eko and Andayani. 2017. Effect of Capital Structure, Size, Profitability on Firm Value with Growth as a Moderating Variable. Journal of Science and Accounting Research Vol 6, No. 6. ISSN 2460-0585.

Boedileksmana and Gunawan. 2003. "The Influence of Indicators of the Company's Financial Ratios with PER and PBV on Stock Return Portfolios on the JSX". Journal of Accounting and Investment Vol. 4 No. 2.

Brigham, EF., And J. Houston. 2010. Fundamentals of Financial Management. Tenth Edition. Salemba Empat Publisher, Jakarta.

Brealey, R.A dan Myers, S. C. 2003. Principles of Corporate Finance. Seventh Edition. New York: McGraw-Hill.

Catrinasari, Renny. 2006. "Factors Influencing the Timeliness of Financial Reporting in Public Banking in the Jakarta Stock Exchange. Indonesian Islamic University: Yogyakarta.

Chaidir 2015. The Influence of Capital Structure, Profitability, and Company Growthon the Value of Companies in the Transportation Sub Sector Listed on the Indonesia Stock Exchange for the 2012-2014 Period. JIMFE, 1 (2), pp. 1-21. Cristiawan, Y. J. And J. Taringan. 2015. Managerial Ownership: Debt Policy, Performance, and Corporate Value, Journal of Accounting and Finance 9 (1): 1-8.

Chowdhury, Anup dan S.P Chowdhury. 2010 Impact of Capital Structure on Firm's Value: Evidence from Bangladesh. Business and Economic Horizons. Vol 3. October 2010. Pp. 111-112.

Christianti, A. 2006. Determination of Capital Structure Policy Behavior in Manufacturing Companies in the Jakarta Stock Exchange: Static Tradeoff Hypothesis or Pecking Order Theory. National Seminar on Accounting.

Damodaran, Aswath. 2001. Corporate Finance: Theory and Practice. International Edition, Willey. New York.

Dewa Ayu and Gede Mertha. 2017. Effect of Profitability, Firm Size, and Asset Growth on Capital Structure and Firm Value. E Journal of Management Unud Vol 6, No. 4. ISSN 2302-8912.

Dewi Maha Y and Sudiartha M. 2017. Effect of Profitability, Company Size, and Asset Growth on Capital Structure and Company Value. Unud Management E-journal, Vol. 6, No. 4

Dyah Putri Pratiwi. 2017. Effect of Growth Opportunity, Profitability and Company Size on Company Value. Journal of Science and Accounting Research Vol.6, No. 2. ISSN 2460-0585.

Driffeild, N., V. Mahambare, and S.Pal. 2007. "How Does Ownership Structure Affect Capital Structure and Firm Value? Recent Evidence From East 
Asia". (online), (www.google.com).

Fakruddin, M and Hadianto M. 2001. Tools and Models of Investment Analysis in the Capital Market. Jakarta: Gramedia.

Febrianti, Meiriska. 2012. Factors Affecting Company Value in the Mining Industry on the Indonesia Stock Exchange. Journal of Business and Accounting. 14 (2), pp. 141-156.

Ferdinand. 2006 Management Research Methods: Research Guidelines for Thesis, Thesis and Dissertation in Management Science. Semarang: Diponegoro University.

Gamaliel, Joshua., And Luh Komang Sudjarni. 2015. Effect of Profitability, Company Size and Asset Structure on Capital Structure in Transportation Companies on the IDX. E-Journal of Management of Udayana University, 4 (1), pp. 59-74.

Gultom, Robinhot et al. 2013. Analysis of Factors Affecting Company Value in Pharmaceutical Companies on the Indonesia Stock Exchange. Journal of Microeconomic Entrepreneurs, Vol. 3 things. 1

Ghozali, Imam. 2012. Multivariate Analysis Application with the IBM SPSS Program. Yogyakarta: Diponegoro University.

Hamidy, et al. 2015. The Effect of Capital Structure on Company Value with Profitability as Intervening Variables in Property Companies and Real Estate on the Indonesia Stock Exchange. E-Journal of Economics and Business, Udayana University. Vol 4 (10).

Hariyawan, Eko and Andayani. 2017. Effect of Capital Structure, Size, Profitability on Firm Value with Growth as a Moderating Variable. Journal of Accounting and Research. Vol 6 (6).

Hasnawati, S. 2005. Implications of Investment Decisions, Funding, and Dividends on the Value of Public Companies on the Jakarta Stock Exchange. Businessman: N0. 09 / Th XXXIX

Hargiansyah, R. F. 2015. Effect of Company Size, Leverage, and Profitability on Company Value (Empirical Study of Manufacturing Companies Listed on the Indonesia Stock Exchange). Accounting journal. University of Jember. Jember

Hartono Jogiayanto and Bandi. 2000. Behavioral Intermediate Accounting Reaction Price and Volume of Stock Trading towards Dividends. Indonesian Research Journal. vol. 1, No. 2, July: 203-213

Hidayati, 2010. Analysis of the Effect of DER, DPR, ROE, and Size on PBV Manufacturing Companies Listed on the Indonesia Stock Exchange Period 2005-2007. Thesis. Diponegoro University. Semarang.

Husnan, Suad and Enny Pudjiastuti. 2006. Fundamentals of Financial Management.

Fifth Edition. UPP STIM YKPN: Yogyakarta.

Hermuningsih, Sri. 2013. The Effect of Profitability, Growth Opportunity, Capital Structure, Against the Value of Public Companies in Indonesia. Bulletin of Monetary Economics and Banking, 16 (2), pp. 127-148.

ICMD.2016. Indonesian Capital Market Directory. Jakarta, Indonesia.2016.

Isabella and A.A Gde Satia. 2017. Effect of Company Growth, Capital Structure and profitability on firm value. Airlangga Journal of Accounting and 
Business Research Vol. 2 No. 1. ISSN 2548-1401.

Indriantoro, N and B. Supomo. 2008. Business Research Methodology for Accounting and Management. First edition. BPFE. Yogyakarta.

Ju Chen dan Yu Chen . (2011). The influence of profitability on firm value with capital structure as the mediator and firm size and industry as moderators. Investment Management and Financial Innovations journal, Volume 8, Issue 3, 2011.

Kartini and A. Tulus. 2008. Ownership Structure, Profitability, Asset Growth and Company Size of Capital Structure in Manufacturing Companies, Journal of Finance and Banking, 12 (1). 11-21

Kaaro, Hermeindito. (2003). Capital Structure Prediction Based on Pecking Order Theory in Normal Economic Conditions and Economic Crisis. STIE Widya Wiwaha Yogyakarta Business Study, No. 28 (JanuaryApril), 51-66.

Kamila and Yuniati. 2017. Effect of Company Size, Leverage, Profitability, and Capital Structure on Company Value. Journal of Management Science and Research Vol. 6 No. 3

Cashmere. 2013. Financial Statement Analysis. Rajawali Press: Jakarta Kusumajaya, D.K.O. 2011. Effect of capital structure and company growth on

profitability and firm value in manufacturing companies on the Indonesia stock exchange. Udayana University, Denpasar: Unpublished thesis

Keown, Arthur J. 2000. Fundamentals of Financial Management Book 2 (Translation). Jakarta: Salemba Empat.

Mai, MU 2006. Analysis of Variables Affecting the Capital Structure of LQ-45 Companies on the Jakarta Stock Exchange, Economics, Pg. 228-245. State Polytechnic, Bandung.

Maryati Rahayu, Bida Sari. 2018. Factors Affecting Company Value. IkraithHumaniora, Vol.2, No. 2

Myers, S.C \& Majulif, N. 1984. Corporate Financing and Investments Decisions When Firms Have Investments That Investors Do Not Have. Journal of Financial Economics, 13 (2): 187-221.

Murhadi R. Werner. 2011. "Determinants of Capital Structure: Studies in Southeast Asia" Journal of Management and Entrepreneurship, Vol. 13, No. 2

Munawaroh and Priyadi. 2014. The Effect of Profitability on Company Value with Corporate Social Responsibility as a Moderating Variable. Journal of Accounting Science \& Research Vol. 3 No. 4.

Modigliani, F. and MH. Miller. 1963. The cost of capital, corporation finance and the theory of investment. American Economic Review. 47 (3): 261297.

Moniaga, Fernandes. 2013. "Capital Structure, Profitability, Cost Structure of the Corporate Value of the Ceramic Industry, Porcelen and Glass Period 2007- 2011". EMBA Journal ISSN 2303-1174 Vol. 1 No. 4 things. $433-$ 442.

Ni Gusti Putu Wirawati. (2013). "Influence of inflation, Rupiah Exchange Rates, SBI Interest Rates on the Composite Stock Price Index on the IDX". 
Journal of Accounting at Udayana University.

Pratama, Angga I Gusti Bagus and Wiksuana, I Gusti Bagus. (2016). Effect of Company Size and Leverage on Firm Value with Profitability as Mediation Variables. E-Management Journal of Udayana University, Vol (2), 1338- 1367.

Pratiwi P and Amanah. 2017. Effect of Opportunity, Profitability and Company Size on Company Value. Journal of Accounting Science and Research, Vol 6 (2)

Putrakrisnanda. 2009. Factors Affecting Capital Structure of Manufacturing Companies in Indonesia (online), (www..scribd.com).

Rachmawati, Amalia Dewi., Topowijoyo., And Sri Sulasmiyanti. 2015. The Effect of Company Size on Profitability, Capital Structure, and Investment Decisions on Firm Value: Study of Real Estate and Building Construction Companies in the Indonesia Stock Exchange Period 20102013. Journal of Business Administration, 23 (2), pp. 1-15.

Reilly, Frank K., and Keith C. Brown. 2000. Investment Analysis and Portfolio Management. Six Edition. The Drryden Press, USA.

Riyanto Bambang. 2011. Fundamentals of Corporate Expenditures. BPFE, Yogyakarta.

Robert, Ang. 1997. Smart Book of the Indonesian Capital Market. (The Intelegent Guide to Indonesia Capital Market). Mediasoft Indonesia. Jakarta

Roosiana Ayu and Maswar P Priyadi. 2016. The Effect of Leverage, Profitability, Size and Growth Opportunity on Company Value. Journal of Management Science and Research Vol. 7, No. 10. ISSN 2461-0593.

Saidi, 2004, Factors Affecting Capital Structure in Go Public Manufacturing Companies on the JSE 1997-2002, Journal of Business and Economics, Vo.XI (1).

Salvatore, D. 2005. Managerial Economics in the Global Economy. Salemba Empat: Jakarta.

Sari and Sidiq. 2013. Analysis of Financial Leverage, Profitability and Earning Per Share of Company Value in Manufacturing Industries Listed on the Indonesia Stock Exchange (BEI), Journal of Management \& Accounting Research, Vol. 4, No. 7

Sartono, R. A. 2008. Financial Management Theory and Applications, Fourth Edition. BPFE. Yogyakarta.

Sudarmadji, Murdoko, and Sularto. 2007. Effect of Company Size, Profitability, Leverage, and Type of Ownership on Voluntary.

Sugihono. 2008. Business Research Methods. Alfabeta: Bandung.

Suguhen. 2003. The Influence of Capital Structure on Productivity of Assets and Financial Performance and the Value of Manufacturing Companies in Indonesia. Dissertation. (online), (www.google.com).

Sugiharto (2009). Capital Structure, Company Ownership Structure, Agency Problems and Asymmetric Information. Graha Ilmu Yogyakarta.

Sujoko and Soebiantoro, U. 2007. Effect of Structure of Share Ownership, Leverage, Internal Factors and External Factors on Company Value, Journal of Management and Entrepreneurship Vol 9 (1). 
Suwardika and Mustanda. 2017. Effect of Leverage, Company Size, Company Growth and Profitability on Company Value in Property Companies. Management E-Journal of Udayana University, Vol. 6/3

Setiyadi.2007. Effect of Company Size, Profitability, \& Institutional Ownership on CSR Disclosure. Journal of Economics. Bandung: Padjadjaran University.

Soliha and Taswan. 2002. The Effect of Debt Policy on Company Value and the Factors Affecting it. In the Journal of Business and Economics, STIE Stikubank Semarang. (online), (www.google.com).

Sriwardany. 2006. The Effect of Company Growth on Capital Structure Policy and Its Impact on Changes in Stock Prices in Manufacturing Companies. Thesis. (online), (www.google.com).

Tandellin, Eduardus. 2001. Investment Analysis and Portfolio Management. First edition. Yogyakarta: BPFE.

Taswan 2003. Analysis of the influence of Insider Ownership, Debt and Dividend Policy on Company Value and Factors Affecting it. Journal of Economics and Business. Vol. 10 No. 2. Pp. 162-181.

Wahyuni, Tri., Endang Erawati, SE., M.Sc and Dr. Werner R. Murhadi, SE., MM. 2013. Factors Affecting Company Value in the Real Estate \& Building Construction Sector which are Listed on the Indonesia Stock Exchange Period 2008 - 2012. Surabaya Student Scientific Journal, 2 (1), pp. 1-18.

Wardana, Arya Ditha I Putu., And big Merta Merta Sudiartha. 2015. The Effect of Liquidity, Company Size, Business Risk, and Age of the Company on the Capital Structure in the BEI Tourism Industry for the period 2010-2015. E-Journal of Management of Udayana University, 4 (6), pp: 1710-1721.

Wardjono. 2010. "Analysis of Factors Affecting Price to Book Value and Its Implications on Stock Returns". Financial and Banking Dynamics, Vol. 2 No. 1

Weston, J. F and Copeland. 2008. Fundamentals of Financial Management Volume II. Jakarta: Erlangga.

Sriwardany. 2006. The Effect of Company Growth on Capital Structure Policy and Its Impact on Changes in Stock Prices in Manufacturing Companies. Thesis. (online), (www.google.com).

Tandellin, Eduardus. 2001. Analisis Investasi dan Manajemen Portofolio. Edisi Pertama. Yogyakarta: BPFE.

Taswan. 2003. Analisis pengaruh Insider Ownership, Kebijakan Hutang dan Deviden terhadap Nilai Perusahaan serta Faktor-Faktor yang Mempengaruhinya. Jurnal Ekonomi dan Bisnis. Vol. 10 No. 2. Pp. 162181.

Wahyuni, Tri., Endang Erawati, SE., M.Sc and Dr. Werner R. Murhadi, SE., MM. 2013. Factors Affecting Company Value in the Real Estate \& Building Construction Sector which are Listed on the Indonesia Stock Exchange Period 2008 - 2012. Surabaya Student Scientific Journal, 2 (1), pp. 1-18.

Wardana, Arya Ditha I Putu., And big Merta Merta Sudiartha. 2015. The Effect 
of Liquidity, Company Size, Business Risk, and Age of the Company on the Capital Structure in the BEI Tourism Industry for the period 2010-2015. E- Journal of Management of Udayana University, 4 (6), pp: $1710-1721$.

Wardjono. 2010. "Analysis of Factors Affecting Price to Book Value and Its Implications on Stock Returns". Financial and Banking Dynamics, Vol. 2 No. 1.

Weston, J. F and Copeland. 2008. Fundamentals of Financial Management Volume II. Jakarta: Erlangga. 